\title{
Penerapan Hasil Audit Keselamatan Jalan di Lokasi Rawan Kecelakaan Lalu Lintas
}

\author{
Gito Sugiyanto ${ }^{1}$, Ari Fadli², Mina Yumei Santi ${ }^{3}$ \\ 1,2Universitas Jenderal Soedirman Purwokerto \\ ${ }^{3}$ Politeknik Kesehatan Kementerian Kesehatan Yogyakarta dan Pusat Unggulan Inovasi (PUI) Teknologi \\ Terapan bidang Kesehatan Masyarakat, Poltekkes Kemenkes Yogyakarta \\ e-mail: gito.sugiyanto@unsoed.ac.id¹ ${ }^{2}$ arifadli@.unsoed.ac.id²,mina.yumei@poltekkesjogja.ac.id ${ }^{3}$
}

\begin{abstract}
Traffic accidents are increasing along with the increasing number of traffic violations, the increasing number of vehicles, especially motorcycles, and driving vehicles exceeds the maximum allowable speed (speeding). The number of traffic accidents and the number of accident victims is increasing every year. Data from the National Police Traffic Corps, road transportation accidents in 2019 recorded 107,500 cases with 23,530 fatalities. The most vulnerable road users are pedestrians, non-motorized vehicle users, children, and elderly people. The solution proposed is by mapping traffic accident-prone locations, conducting road safety audits at black spot locations to determine the conditions and handling efforts to reduce accident events in the form of installing traffic signs. The results of the road safety audit revealed that there had been a deficiency of road infrastructure in Tlahab Lor road section. The recommendation made is by installing traffic signs. Handling of black spot locations on the Tlahab Lor road that is by installing 4 vehicle maximum limit signs of 40 and $30 \mathrm{~km} / \mathrm{h}$. After knowing the location of black spot people is expected to be more alert and careful when passing through these roads.
\end{abstract}

Keywords: traffic safety, accident, road safety audit, speed limit, black spot

\begin{abstract}
Abstrak
Kecelakaan lalu lintas semakin meningkat seiring dengan meningkatnya jumlah pelanggaran lalu lintas, bertambahnya jumlah kendaraan khususnya sepeda motor, dan mengendarai kendaraan melebihi batas kecepatan maksimum yang diijinkan (speeding). Data Korlantas Polri, kecelakaan transportasi jalan pada tahun 2019 tercatat 107.500 kasus dengan jumlah korban meninggal dunia mencapai 23.530 orang. Pengguna jalan yang paling rentan adalah pejalan kaki, pengguna kendaraan tidak bermotor, anak-anak dan manusia lanjut usia. Solusi yang diusulkan yaitu dengan melakukan pemetaan lokasi rawan kecelakaan lalu lintas, melakukan audit keselamatan jalan di lokasi rawan kecelakaan untuk mengetahui kondisi daerah rawan kecelakaan dan upaya penanganan untuk mengurangi peristiwa kecelakaan baik berupa pemasangan rambu lalu lintas. Hasil audit keselamatan jalan diperoleh bahwa telah terjadi defisiensi infrastruktur jalan di ruas jalan Tlahab Lor. Rekomendasi yang dilakukan yaitu dengan memasang ramburambu lalu lintas. Penanganan lokasi rawan kecelakaan di ruas jalan Desa Tlahab Lor yaitu dengan memasang 4 buah rambu batas maksimum kendaraan 40 dan 30 km/jam. Setelah mengetahui lokasi rawan kecelakaan diharapkan masyarakat akan menjadi lebih waspada dan berhati-hati ketika melewati ruas jalan tersebut.
\end{abstract}

Kata kunci: keselamatan lalu lintas, kecelakaan, road safety audit, kecepatan maksimum, black spot

\section{PENDAHULUAN}

Keselamatan lalu lintas jalan di Indonesia kondisinya cukup memprihatinkan yang ditunjukkan dengan tingginya angka kecelakaan lalu lintas dan jumlah korban kecelakaan. Data Korlantas Polri, kecelakaan transportasi jalan pada tahun 2016 tercatat 106.129 kasus dengan jumlah korban meninggal dunia 26.185 orang, korban luka berat 22.558 orang, korban luka ringan 121.550, dan kerusakan harta benda mencapai Rp 226.883.000.000,00 [1]. Angka kecelakaan lalu lintas semakin meningkat seiring dengan bertambahnya jumlah kendaraan khususnya sepeda motor, meningkatnya pelanggaran rambu lalu lintas dan mengendarai kendaraan melebihi batas kecepatan maksimum yang diijinkan atau speeding [2-4]. Kecelakaan lalu lintas menjadi penyebab kematian urutan ke-8 pada tahun 1990 dan naik menjadi urutan ke-6 pada tahun 2017 [5]. Untuk meminimalkan defisiensi infrastruktur jalan, terdapat tiga aspek yaitu jalan yang pemaaf yang mampu meminimalisir keparahan korban apabila tabrakan 
(forgiving road), jalan yang mampu menjelaskan maksud tanpa komunikasi (self-explaining road), dan jalan yang mampu menciptakan kepatuhan tanpa peringatan (self-regulating road) [6]. Mobilitas adalah salah satu komponen yang berkontribusi terhadap kecelakaan lalu lintas [7-9], oleh karena itu, model keselamatan jalan difokuskan terutama pada faktor risiko [10].

Di Kabupaten Purbalingga, Provinsi Jawa Tengah berdasarkan data kecelakaan lalu lintas dari Satuan Lalu Lintas Polres Purbalingga, dalam kurun waktu 2 tahun yaitu tahun 2016 dan 2017 terjadi 1130 kasus kecelakaan lalu lintas. Jumlah korban meninggal dunia sebanyak 189 orang, korban luka berat 5 orang, korban luka ringan 1646 orang, dan jumlah kerugian material mencapai $\mathrm{Rp} 617.750 .000,00$ [11]. Jumlah kecelakaan lalu lintas yang tinggi menunjukkan adanya berbagai macam faktor penyebab kecelakaan. Salah satu upaya untuk mengurangi angka kecelakaan lalu lintas adalah dengan melakukan penentuan dan penanganan lokasi rawan kecelakaan lalu lintas. Menurut Pd T-09-2004-B lokasi rawan kecelakaan lalu lintas adalah suatu lokasi dimana angka kecelakaan tinggi dengan kejadian kecelakaan berulang dalam suatu ruang dan rentang waktu yang relatif sama yang diakibatkan oleh suatu penyebab tertentu [12].

Menurut Direktur Keselamatan Transportasi Darat (DKTD) diperkirakan bahwa kerugian yang dipikul akibat kecelakaan lalu lintas pada tahun 2002 sebesar Rp 41,4 trilyun [13]. Padahal diketahui bahwa jumlah kecelakaan yang tercatat di Indonesia hanya sekitar 8\% dan sebagian besar yang tidak tercatat merupakan kecelakaan tanpa korban jiwa [13]. Kecelakaan lalu lintas merupakan masalah kesehatan yang pontensial di Indonesia seiring makin giatnya pembangunan akhir-akhir ini. Menurut World Health Organization dalam dua tahun terakhir ini, kecelakaan lalu lintas di Indonesia dinilai menjadi pembunuh terbesar ketiga, di bawah penyakit jantung koroner dan Tuberculosis atau TBC. Global Status Report on Road Safety 2013 menempatkan Indonesia sebagai negara urutan kelima tertinggi angka kecelakaan lalu lintas di dunia [14]. Di Indonesia, sebagian besar kecelakaan lalu lintas yaitu 70\% adalah pengendara sepeda motor yang berusia produktif dengan rentang usia 15-59 tahun yaitu lebih tinggi pada laki-laki sebanyak 31,9\% dibandingkan dengan perempuan yaitu 19,8\% [15]. Penerapan biaya kemacetan atau congestion pricing di kawasan central business district [16-17], penerapan biaya kemacetan untuk pengguna mobil pribadi [18], identifikasi lokasi rawan kecelakaan lalu lintas [2], adalah berbagai metode yang telah dicoba untuk mengurangi biaya transportasi darat di Indonesia. Penelitian terkait keselamatan lalu lintas yang sudah dilakukan sebelumnya di wilayah Eropa, menunjukkan bahwa kecelakaan lalu lintas cenderung terkonsentrasi di ruas jalan tertentu. Beberapa parameter yang digunakan untuk menganalisa penyebab kecelakaan di jalan raya adalah geometrik jalan raya, perilaku mengemudi, kondisi cuaca, dan batas kecepatan [19]. Hal itu menunjukkan bahwa selain faktor kesalahan pengemudi, karakteristik jalan menjadi salah satu faktor penting dalam terjadinya kecelakaan lalu lintas di jalan raya.

Sugiyanto dan Santi [20] menyatakan bahwa ada tiga faktor penyebab kecelakaan lalu lintas, yaitu faktor manusia, kendaraan, dan lingkungan. Penyebab kecelakaan lalu lintas yang paling banyak di Indonesia disebabkan oleh faktor manusia (91\%). Faktor kedua kecelakaan sebanyak $5 \%$ adalah faktor kendaraan, dan faktor jalan sebanyak 3\% serta faktor lingkungan sebesar 1\% [13]. World Health Organization mencatat hampir 1,2 juta orang di seluruh dunia setiap tahun tewas akibat kecelakaan di jalan. Jutaan lagi mengalami cedera dan sebagian lagi mengalami cacat seumur hidup [21]. Salah satu upaya untuk menurunkan angka kecelakaan lalu lintas yaitu melalui pendidikan keselamatan sejak dini [22].

\section{METODE}

Data kecelakaan lalu lintas diperoleh dari Satlantas, Polisi Purbalingga dari 1 Januari 2016 sampai dengan 31 Desember 2017 [11]. Data ini digunakan untuk menentukan lokasi rawan kecelakaan lalu lintas menggunakan angka ekivalen kecelakaan dan metode upper control limit [23] [24]. Metode yang digunakan dalam kajian ini adalah statistik kendali mutu. Nilai angka ekivalen kecelakaan berdasarkan nilai pembobotan korban MD: LB: LR: PDO = 10: 5: 1: 1 . 
Penentuan lokasi rawan kecelakaan lalu lintas menggunakan statistik kendali mutu sebagai control-chart UCL atau Upper Control Limit, seperti ditunjukkan pada Persamaan 1.

$\left.\mathrm{UCL}=\lambda+\Psi \times \sqrt{\left(\frac{\lambda}{m}\right.}+\frac{0.829}{m}+\left(\frac{1}{2} x m\right)\right)$

dimana: $\quad \lambda=$ nilai rata-rata angka kecelakaan.

$\Psi=$ faktor probabilitas sebesar 2,576.

$\mathrm{m}=$ nilai kecelakaan di setiap segmen.

Jika suatu segmen ruas jalan memiliki nilai tingkat kecelakaan (jumlah AEK) berada di atas garis UCL maka segmen ruas jalan tersebut diidentifikasi sebagai lokasi rawan kecelakaan lalu lintas [12]. Nilai faktor probabilitas $(\Psi)$ ditentukan oleh probabilitas bahwa tingkat kecelakaan cukup besar sehingga kecelakaan tidak dapat dianggap sebagai kejadian acak [25]. Nilai faktor probabilitas $(\Psi)$ yang sering digunakan yaitu 2,576 dengan probabilitas 0,005 (nilai signifikansi 99,5\%) dan 1,645 dengan probabilitas 0,05 (atau nilai signifikansi 95\%).

\section{HASIL DAN PEMBAHASAN}

\subsection{Lokasi Rawan Kecelakaan Lalu Lintas}

Penentuan nilai Upper Control Limit (UCL) dilakukan untuk mengetahui batas tingkat kerawanan kecelakaan tiap ruas jalan, dimana tiap ruas jalan memiliki batas tingkat kerawanan kecelakaan yang berbeda-beda. Perhitungan ini menjadi acuan untuk menentukan ruas jalan yang rawan kecelakaan lalu lintas di Kabupaten Purbalingga. Hasil analisis nilai UCL selengkapnya ditunjukkan pada Tabel 1.

Tabel 1. Nilai angka ekivalen kecelakaan dan upper control limit

\begin{tabular}{|c|c|c|c|c|c|c|c|}
\hline \multirow{2}{*}{ No. } & \multirow{2}{*}{ Nama ruas jalan } & \multicolumn{5}{|c|}{ Angka Ekivalen Kecelakaan } & \multirow{2}{*}{ UCL } \\
\hline & & MD & LB & LR & PDO & AEK & \\
\hline & $\begin{array}{l}\text { Jalan Raya turut Dukuh Bayeman, Desa Tlahab Lor, Kec. } \\
\text { Karangreja, Purbalingga }\end{array}$ & 90 & 0 & 16 & 0 & 106 & 50,683 \\
\hline 2. & Jalan Raya Mayjend. Sungkono turut Desa Kalimanah & 30 & 0 & 15 & 0 & 45 & 44,290 \\
\hline 3. & Jalan Raya turut Desa Bojongsari, Purbalingga & 30 & 0 & 15 & 0 & 45 & 44,290 \\
\hline 4. & Jalan Raya turut Desa Brobot, Kec. Bojongsari & 30 & 0 & 10 & 0 & 40 & 43,628 \\
\hline & Jalan Raya turut Desa Banjarkerta, Karanganyar, Pbg & 30 & 0 & 8 & 0 & 38 & 43,355 \\
\hline 6. & Jalan Raya turut Desa Gembong, Kec. Bojongsari & 20 & 0 & 10 & 0 & 30 & 42,208 \\
\hline & Jalan Raya turut Desa Penolih, Kec. Kaligondang & 20 & 0 & 10 & 0 & 30 & 42,208 \\
\hline & Jalan Raya turut Desa Kembangan, Kec. Bukateja & 20 & 0 & 9 & 0 & 29 & 42,058 \\
\hline & Jalan Raya turut Pagutan Desa/Kec. Bojongsari & 20 & 0 & 5 & 0 & 25 & 41,447 \\
\hline 10. & Jalan Raya turut Desa Panican, Kec. Kemangkon & 20 & 0 & 3 & 1 & 24 & 41,292 \\
\hline & Jalan Raya turut Desa Banjarsari, Kec. Bobotsari & 20 & 0 & 4 & 0 & 24 & 41,292 \\
\hline & Jalan Raya turut Desa Wirasaba, Kec. Bukateja & 20 & 0 & 0 & 0 & 20 & 40,662 \\
\hline & Jalan Raya turut Desa Selaganggeng, Kec. Mrebet & 10 & 0 & 5 & 0 & 15 & 39,890 \\
\hline & Jalan Raya turut Desa Selakambang, Kaligondang, Pbg & 10 & 0 & 3 & 0 & 13 & 39,610 \\
\hline & Jalan Raya turut Desa Kutasari, Kec. Kutasari & 10 & 0 & 3 & 0 & 13 & 39,610 \\
\hline \multirow{2}{*}{\multicolumn{2}{|c|}{ 16. Jalan Raya turut Desa Jetis, Kec. Kemangkon }} & 10 & 0 & 3 & 0 & 13 & 39,610 \\
\hline & & 390 & 0 & 119 & 1 & 510 & \\
\hline
\end{tabular}

\subsection{Kondisi Geometrik Jalan Turut Desa Tlahab}

Ruas jalan raya turut Desa Tlahab terletak di Kecamatan Karangreja, Kabupaten Purbalingga termasuk Jalan Provinsi dan merupakan ruas jalan dengan fungsi jalan kolektor. Ruas jalan yang merupakan jalur penghubung antara Kecamatan Bobotsari dan Kabupaten Pemalang ini menggunakan perkerasan lentur dengan kondisi yang cukup baik. Ruas jalan ini berada pada kondisi geografis berupa pegunungan dengan gradien jalan yang cukup besar 
sehingga memiliki jarak pandang yang pendek pada beberapa titik. Lokasi rawan kecelakaan lalu lintas (black spot) berada di depan SD Negeri 1 Tlahab Lor. Jalan Raya Turut Desa Tlahab memiliki lebar total badan jalan sebesar 7,00 m dengan lebar lajur jalan sisi arah Pemalang selebar 3,40 m dan sisi arah Bobotsari selebar 3,60 m. Jalan raya turut Desa Tlahab hampir sepanjang ruasnya tidak memiliki bahu jalan karena sebagian besar berbatasan langsung dengan tebing ataupun jurang yang cukup curam. Sementara itu trotoar dan median jalan juga tidak ada. Beda elevasi bahu jalan dan tepi perkerasannya sebesar $44 \mathrm{~cm}$ pada sisi arah Pemalang dan $24 \mathrm{~cm}$ pada sisi arah Bobotsari. Beda elevasi yang besar ini dikarenakan tepi perkerasan jalan sebagian besar berbatasan langsung dengan selokan karena tidak memiliki bahu jalan. Berdasarkan Pedoman Perencanaan Geometrik Jalan Antar Kota (1997), lebar minimum bahu jalan adalah $150 \mathrm{~cm}$ dan lebar jalan adalah 6,00 $\mathrm{m}$ [26]. Tata guna lahan di sekitar ruas jalan sebagian besar berupa perkebunan warga [27]. Kondisi parameter geometrik jalan dapat dilihat pada Gambar 1.
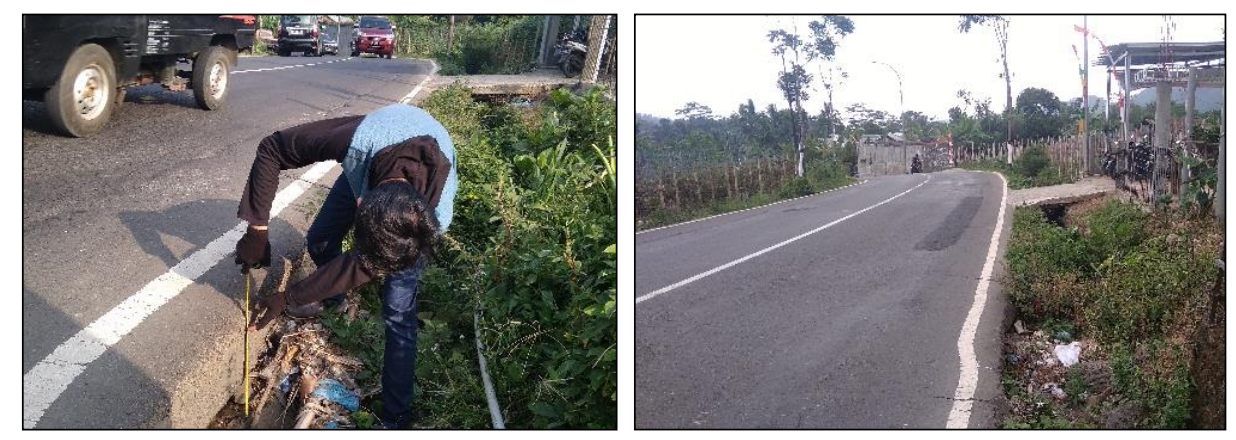

Gambar 1. Beda elevasi bahu jalan dan tepi perkerasan jalan raya turut Desa Tlahab [26]

\subsection{Kecepatan Kendaraan}

Kecepatan kendaraan di ruas jalan Desa Tlahab, Karangreja diambil dengan menggunakan alat speed gun bussnell. Data kecepatan kendaraan yang diukur di jalan raya turut Desa Tlahab adalah sepeda motor 75 kendaraan, mobil penumpang 50 kendaraan, pick up 30 kendaraan, truk kecil 30 kendaraan, truk besar 12 kendaraan, bus kecil 17 dan bus besar 2 kendaraan. Analisis statistik data kecepatan kendaraan di jalan raya turut Desa Tlahab dapat dilihat pada Tabel 2 dan data kurva S kecepatan kendaraan dapat dilihat pada Gambar 2.

Tabel 2. Analisis statistik kecepatan kendaraan di jalan raya turut Desa Tlahab

\begin{tabular}{lccccccc}
\hline Analisis Statistik & $\begin{array}{c}\text { Sepeda } \\
\text { Motor }\end{array}$ & $\begin{array}{c}\text { Mobil } \\
\text { Penumpang }\end{array}$ & Pick-up & $\begin{array}{c}\text { Truk } \\
\text { Kecil }\end{array}$ & $\begin{array}{c}\text { Truk } \\
\text { Besar }\end{array}$ & $\begin{array}{c}\text { Bus } \\
\text { Kecil }\end{array}$ & $\begin{array}{c}\text { Bus } \\
\text { Besar }\end{array}$ \\
\hline Mean (km/jam) & 47 & 40 & 36 & 35 & 33 & 32 & 37 \\
\hline Modus (km/jam) & 50 & 37 & 29 & 34 & 37 & 30 & 41 \\
\hline Median (km/jam) & 48 & 40 & 33 & 35 & 36 & 30 & 37 \\
\hline Variance (km/jam) & 42 & 53 & 82 & 91 & 54 & 17 & 41 \\
\hline Standar deviasi & 6 & 7 & 9 & 10 & 7 & 4 & 6 \\
\hline Max (km/jam) & 65 & 60 & 64 & 56 & 43 & 38 & 41 \\
\hline Min (km/jam) & 34 & 27 & 22 & 18 & 21 & 25 & 32 \\
\hline Jumlah Data & 75 & 50 & 30 & 30 & 12 & 17 & 2 \\
\hline Persentil 15 & 39 & 32 & 28 & 30 & 21 & 25 & 31 \\
\hline & 52 & 46 & 45 & 42 & 38 & 36 & 40 \\
\hline
\end{tabular}




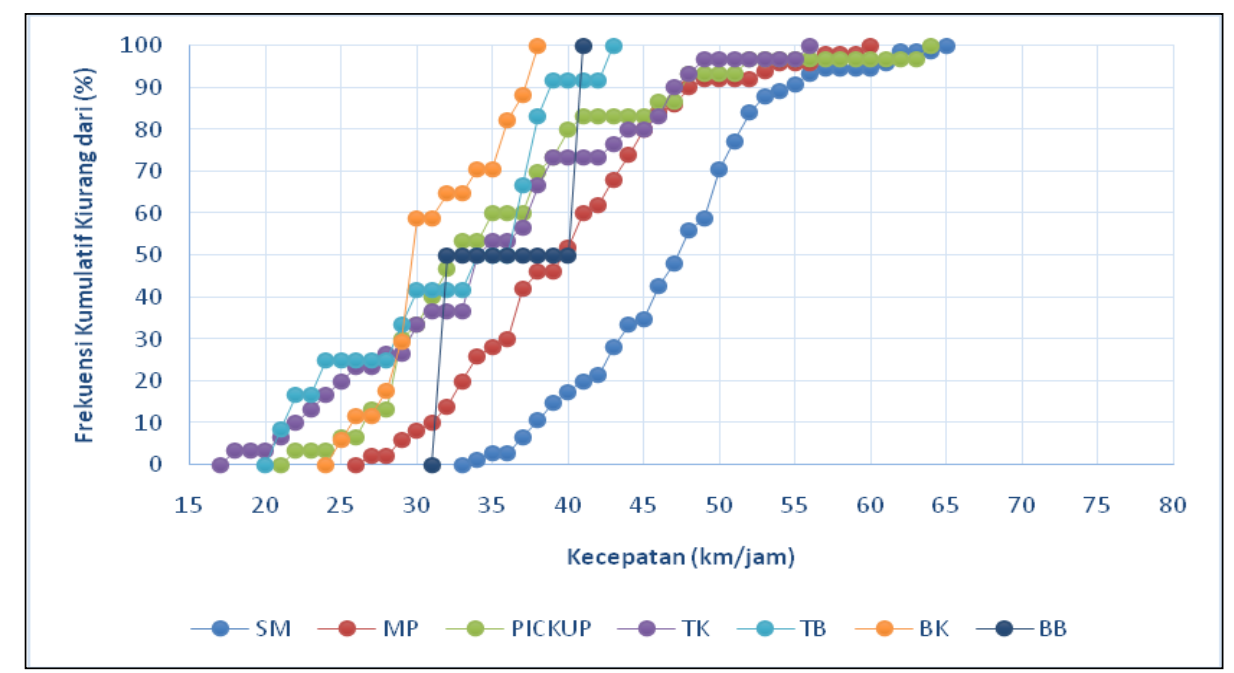

Gambar 2. Kurva S kecepatan kendaraan di jalan raya turut Desa Tlahab, Karangreja, Purbalingga

Dari Tabel 2 dan Gambar 2 dapat diperoleh informasi kecepatan persentil 85 untuk masing-masing jenis kendaraan serta jumlah sampel data kendaraannya. Dikarenakan hanya diambil satu nilai batas kecepatan maksimum yaitu nilai kecepatan kendaraan pada persentil 85 maka nilai tersebut diperoleh dari kecepatan persentil 85 masing-masing jenis kendaraan dikali jumlah data, dibagi jumlah total data kendaraan. Dari hasil perhitungan diperoleh nilai kecepatan persentil 85 pada ruas jalan raya turut Desa Tlahab, Karangreja sebesar 46 km/jam.

\subsection{Kondisi Fasilitas Perlengkapan Jalan}

Marka jalan di Jalan Tlahab Lor berada dalam kondisi yang cukup baik dengan marka membujur garis putus-putus dan marka penuh terlihat. Penerangan jalan cukup dengan jarak rata-rata antara lampu penerangan di lapangan $50 \mathrm{~m}$, sedangkan persyaratan standar untuk penerangan jalan adalah $48 \mathrm{~m}$. Lampu lalu lintas, rambu pengarah, dan tanda peringatan sangat kurang mengacu pada standar Peraturan Menteri Perhubungan PM No. 13 Tahun 2014 [28]. Marka jalan mengacu pada standar dari Kementerian Perhubungan PM No. 67 Tahun 2018 [29].

\subsection{Audit Keselamatan Jalan}

Hasil audit keselamatan jalan di ruas jalan turut Desa Tlahab Lor, Karangreja, dari 2 aspek yang ditinjau yaitu geometrik jalan dan fasilitas perlengkapan jalan sebagai berikut:

a. Hasil analisis defisiensi infrastruktur geometrik jalan, dari 4 aspek yang ditinjau yaitu jarak pandang henti, jarak pandang mendahului, lebar lajur, dan lebar bahu, selain dari aspek jarak pandang mendahului semua masuk ke dalam kategori resiko "tidak berbahaya" dan bentuk penanganan berdasarkan kategori resikonya tersebut adalah monitoring secara rutin dengan inspeksi keselamatan jalan yang terjadwal. Dan untuk aspek jarak pandang mendahului masuk ke dalam kategori "cukup berbahaya", artinya perlu adanya penanganan teknis berupa pembuatan marka membujur utuh pada pemisah lajur lalu lintas untuk melarang kendaraan menyiap pada tikungan dan juga rambu larangan menyiap untuk mempertegasnya.

b. Hasil audit harmonisasi fasilitas perlengkapan jalan, untuk rambu batasan kecepatan, rambu peringatan, dan sinyal dikategorikan ke dalam kategori resiko "sangat berbahaya" (SB) artinya dalam hal ini perlu adanya penanganan teknis secara total berupa pemasangan rambu batas kecepatan, rambu peringatan, maupun sinyal. Untuk rambu pengarah masuk ke dalam kategori resiko "berbahaya" (B), artinya penanganan teknis yang terjadwal maksimal 2 bulan sejak hasil audit keselamatan jalan disetujui berupa melengkapi atau memambah rambu pengarah tikungan. Dan untuk fasilitas perlengkapan jalan lainnya yaitu marka dan lampu penerangan jalan dikategorikan ke dalam kategori resiko "tidak berbahaya" (TB) dan bentuk penanganannya berupa monitoring secara rutin dengan inspeksi keselamatan jalan yang terjadwal.

\subsection{Usulan Penanganan Perbaikan Lokasi Black Spot}


Usulan penanganan untuk perbaikan lokasi rawan kecelakaan lalu lintas di ruas Jalan Desa Tlahab Lor, adalah sebagai berikut:

a. Membuat marka membujur solid (padat) pada pemisah lajur untuk melarang kendaraan menyiap di tikungan.

b. Pemasangan rambu batas kecepatan maksimum yaitu $30 \mathrm{~km} / \mathrm{jam}$ dan $40 \mathrm{~km} / \mathrm{jam}$.

c. Pemasangan sinyal satu warna untuk memperingati pengguna jalan agar berhati-hati.

d. Pemasangan rambu pengarah tikungan.

e. Menambah tinggi bahu jalan agar sejajar dengan perkerasan jalan.

\subsection{Pemasangan Rambu Batas Kecepatan Maksimum di Lokasi Black Spot}

Penanganan lokasi rawan kecelakaan di ruas jalan Desa Tlahab Lor, Karangreja yaitu dengan memasang rambu batas kecepatan maksimum kendaraan. Pemasangan rambu batas kecepatan dikoordinasikan dengan pihak Balai Perhubungan Wilayah 5 Dinas Perhubungan Provinsi Jawa Tengah, mengingat ruas jalan Desa Tlahab Lor merupakan jalan provinsi. Terdapat 4 (empat) buah rambu batas kecepatan maksimum kendaraan yang terdiri dari 2 (dua) buah rambu batas kecepatan $30 \mathrm{~km} / \mathrm{jam}$ dan 2 (dua) buah rambu batas kecepatan $40 \mathrm{~km} / \mathrm{jam}$. Penentuan lokasi pemasangan rambu batas kecepatan ditunjukkan pada Gambar 3. Pemasangan rambu batas kecepatan maksimum kendaraan di ruas jalan Desa Tlahab Lor, Karangreja, Purbalingga ditunjukkan pada Gambar 4.
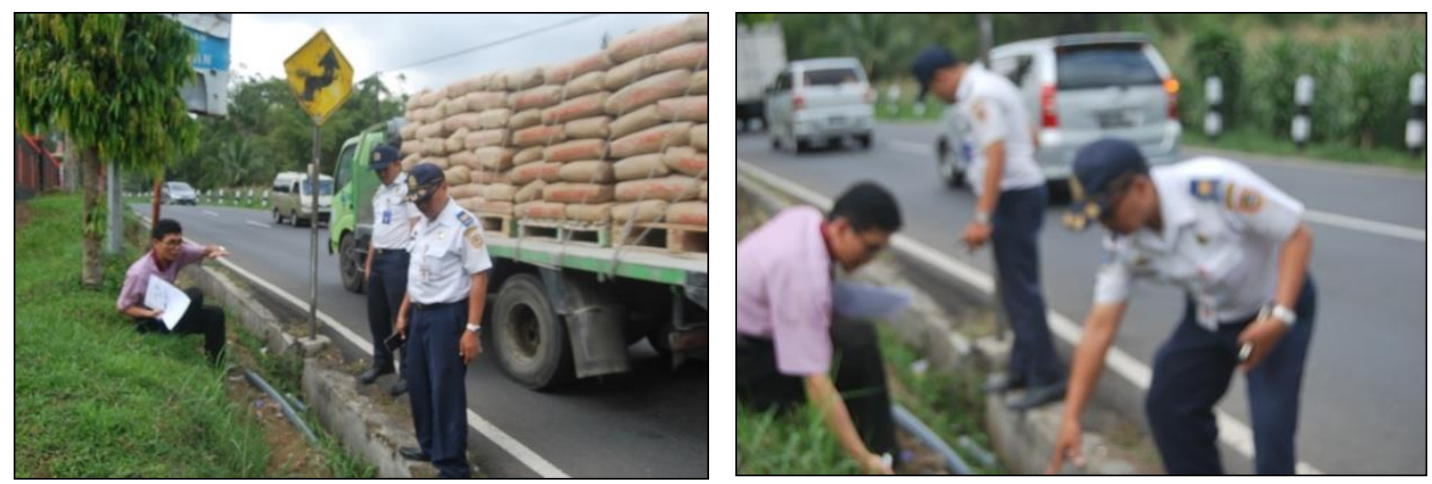

Gambar 3. Penentuan lokasi pemasangan rambu batas kecepatan maksimum di ruas jalan Tlahab
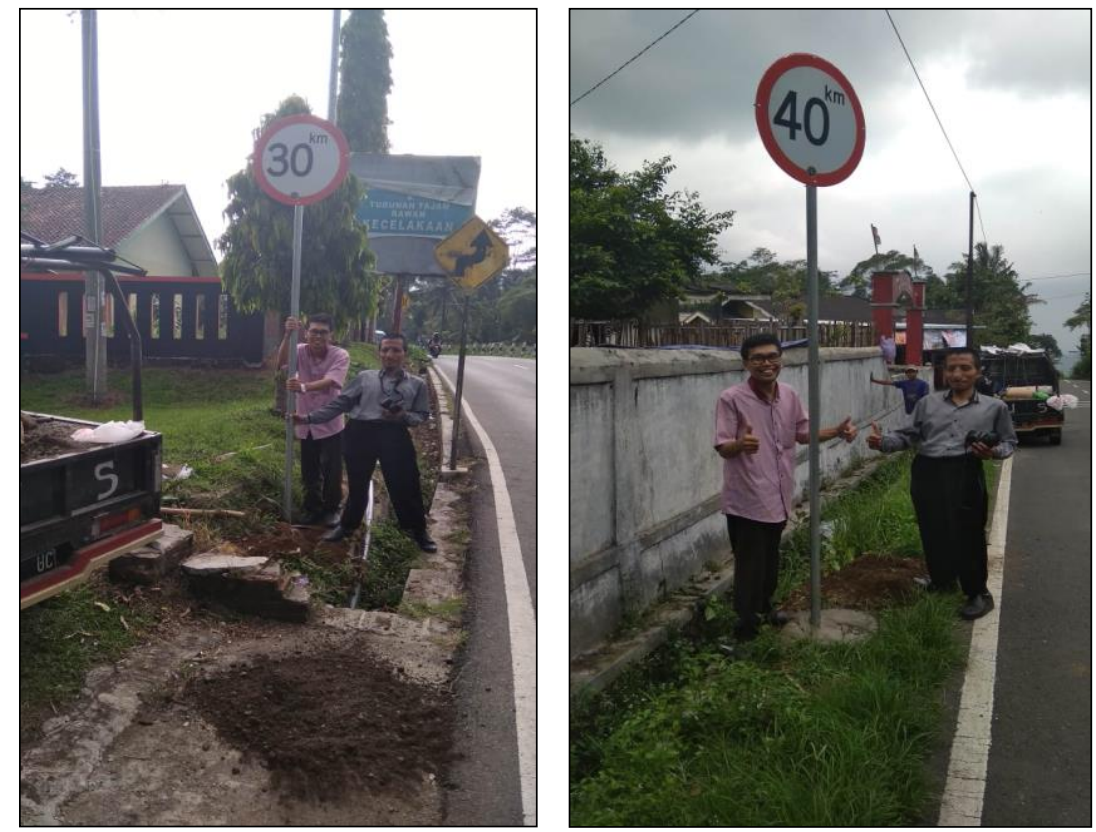

Gambar 4. Pemasangan rambu batas kecepatan maksimum 30 dan 40 km/jam di ruas jalan turut Desa Tlahab, Karangreja, Purbalingga 


\section{KESIMPULAN}

1. Hasil audit keselamatan jalan di ruas jalan Desa Tlahab Lor, Karangreja, Purbalingga yang harus diperbaiki yaitu aspek geometrik meliputi jarak pandang menyiap, beda elevasi jalan dengan bahu, dan aspek harmonisasi fasilitas perlengkapan jalan yaitu tidak terdapat rambu batas kecepatan maksimum dan rambu pengarah tikungan.

2. Penanganan lokasi rawan kecelakaan di ruas jalan Desa Tlahab Lor, Karangreja yaitu dengan memasang rambu batas kecepatan maksimum kendaraan 30 dan 40 km/jam.

\section{UCAPAN TERIMA KASIH}

Penulis mengucapkan terima kasih kepada Direktorat Riset dan Pengabdian Masyarakat, Direktorat Jenderal Penguatan Riset dan Pengembangan, Kementerian Riset, Teknologi, dan Pendidikan Tinggi Republik Indonesia yang telah memberi dukungan finansial terhadap pengabdian ini melalui skim Program Kemitraan Masyarakat (PKM) dengan Kontrak Nomor: 059/SP2H/PPM/DRPM/2019 Tahun Anggaran 2019.

\section{DAFTAR PUSTAKA}

Korps Lalu Lintas (Korlantas) Polri. (2018). Polantas dalam Angka 2016. Jakarta: Korlantas Kepolisian Negara Republik Indonesia.

Sugiyanto, G., Fadli, A., \& Santi, M. Y. (2017). Identification of black spot and equivalent accident number using upper control limit method. ARPN Journal of Engineering and Applied Sciences, 12(2), 528-535. http://www.arpnjournals.org/jeas/research papers/rp 2017/jeas $\underline{01175650}$

Sugiyanto, G., Jajang, \& Santi, M. Y. (2019). The impact of lowering speed limit on mobility and the environment. The $1^{\text {st }}$ International Conference on Material Science and Engineering for Sustainable Rural Development in AIP Conference Proceeding 2094(1) 020019, 1-8. https://doi.org/10.1063/1.5097488.

Sugiyanto, G. \& Malkhamah, S. (2018). Determining the maximum speed limit in urban road to increase traffic safety. Jurnal Teknologi (Sciences and Engineering), 80(5), 67-77. https://doi.org/10.11113/it.v80.10489.

The Institute for Health Metrics and Evaluation (IHME). (2018). Findings from the Global Burden of Disease Study 2017. Retrieved from http://www.healthdata.org/sites/default/files/files/policy report/2019/GBD 2017 Booklet.pdf.

Direktorat Jenderal Bina Marga. (2006). Kajian Kebutuhan Pelaksanaan Keselamatan Jalan di Indonesia. Jakarta: Kementerian Pekerjaan Umum Republik Indonesia.

Hughes, B. P., Anund, A., \& Falkmer, T. (2015). System theory and safety models in Swedish, UK, Dutch and Australian road safety strategies. Accident Analysis and Prevention, 74, 271-278. https://doi.org/10.1016/i.aap.2014.07.017.

Wang, X., Yuan, J., Schultz, G. G. \& Fang, S. (2018). Investigating the safety impact of roadway network features of suburban arterials in Shanghai. Accident Analysis and Prevention, 113, 137-148. https://doi.org/10.1016/j.aap.2018.01.029.

Sugiyanto, G., Fadli, A., Suciningtyas, R., Indriyati, E. W., \& Santi, M. Y. (2019). Road safety audit at black spot area (Case study in Tlahab Lor, Karangreja, Purbalingga). The $1^{\text {st }}$ International Conf. on Material Science and Engineering for Sustainable Rural Development in AIP Conference Proceeding 2094(1) 020020, 1-10. https://doi.org/10.1063/1.5097489.

Schepers, P., Hagenzieker, M., Methorst, R., Wee, B.V., \& Wegman, F. (2014). A conceptual framework for road safety and mobility applied to cycling safety. Accident Analysis and Prevention, 62, 331-340. http://dx.doi.org/10.1016/i.aap.2013.03.032.

Polres Purbalingga. (2018). Data Kecelakaan Lalu Lintas di Kabupaten Purbalingga Tahun 20162017. Polres Purbalingga (tidak dipublikasikan).

Pusat Litbang Prasarana Transportasi. (2005). Penanganan Lokasi Rawan Kecelakaan Lalu Lintas: Pd.T-09-2004-B. Jakarta: Departemen Permukiman dan Prasarana Wilayah, Kementerian Pekerjaan Umum Republik Indonesia. 
Direktorat Keselamatan Transportasi Darat (DKTD). (2006). Manajemen Keselamatan Transportasi Jalan. Naskah Workshop Manajemen Keselamatan Transportasi Darat. Direktorat Jenderal Perhubungan Darat, Kementerian Perhubungan, 13 Desember 2006.

Gresnews. (2014). Indonesia urutan Kelima Negara dengan Kecelakaan tewas tertinggi, Gresnews (Koran), 26 Januari 2014. Retrieved December 7, 2016 from www.gresnews.com/berita/hukum/1530261-Indonesia-urutan-kelima-negaradengankecelakaan-tewas-tertinggi.

Riyadina, W. (2009). Pola determinan sosiodemografi cidera akibat kecelakaan lalu lintas di Indonesia. Majalah Kedokteran Indonesia, 59, 465-469. Retrieved Agustus 10, 2014 from www.Indonesia.digitaljournal.org/index.php/idnmed/article/viewfile/686/685.

Sugiyanto, G. (2008). Biaya kemacetan (congestion charging) mobil pribadi di central business district (studi kasus Kawasan Malioboro Jogjakarta). Media Teknik Sipil, 8(1), 59-66. http://media.sipil.ft.uns.ac.id/index.php/mts/article/view/63/63.

Sugiyanto, G. (2016). The impact of congestion pricing scheme on the generalized cost and speed of motorcycle to the city of Yogyakarta, Indonesia. Journal of Engineering and Applied Sciences, 11(8),

1740-1746. http://medwelljournals.com/abstract/?doi=jeasci.2016.1740.1746.

Sugiyanto, G. (2018). The effect of congestion pricing scheme on the generalized cost and speed of motorcycle. Walailak Journal of Science and Technology (WJST), 15(1), 95-106. http://wjst.wu.ac.th/index.php/wjst/article/view/2347.

Majid, A. \& Mehrzad, M. (2013). Geometric design consistency model based on speed and safety in rural highways in some European Countries: a review. International Journal of Structural and Civil Engineering Research, ISSN: 2319-6009.

Sugiyanto, G. \& Santi, M. Y. (2015). Karakteristik kecelakaan lalu lintas dan pendidikan keselamatan berlalulintas sejak usia dini (Studi kasus di Kabupaten Purbalingga). Semesta Teknika, 18(1), 65-75. http://journal.umy.ac.id/index.php/st/article/view/707.

Direktorat Jenderal Perhubungan Darat. (2004). Cetak Biru Keselamatan Lalu Lintas dan Angkutan Jalan. Jakarta: Direktorat Lalu Lintas dan Angkutan Jalan, Direktorat Jenderal Perhubungan Darat, Kementerian Perhubungan Republik Indonesia.

Saleh, A., Soehardi, F., Anggraini, M. (2017). Implementasi Keselamatan Lalu Lintas untuk Anak Sekolah Dasar yang Berada di Pinggir Jalan Lintas Barat. Dinamisia: Jurnal Pengabdian Kepada Masyarakat, 1(1), 35-38. https://doi.org/10.31849/dinamisia.v1i1.435.

Sugiyanto, G. (2017). The cost of traffic accident and equivalent accident number in developing countries (case study in Indonesia). ARPN Journal of Engineering and Applied Sciences, 12(2),

http://www.arpnjournals.org/jeas/research papers/rp 2017/jeas 0117 5631.pdf.

Sugiyanto, G. \& Santi, M. Y. (2017). Road traffic accident cost using human capital method (Case study in Purbalingga, Central Java, Indonesia). Jurnal Teknologi (Sciences and Engineering), 79(2), 107-116. https://doi.org/10.11113/jt.v79.5375.

Khisty, C. J. \& Kent, B. L. (2003). Dasar-dasar Rekayasa Transportasi (Transportation Engineering: An Introduction). Jakarta: Erlangga.

Direktorat Jenderal Bina Marga. (1997). Tata Cara Perencanaan Geometrik Jalan Antar Kota. Jakarta: Kementerian Pekerjaan Umum Republik Indonesia.

Prasetyo, Y. A. (2018). Penentuan lokasi rawan kecelakaan dengan pendekatan parameter geometrik jalan di kabupaten Purbalingga. Skripsi. Jurusan Teknik Sipil Unsoed Purwokerto.

Kementerian Perhubungan Republik Indonesia. (2014). Peraturan Menteri Perhubungan Republik Indonesia Nomor PM 13 Tahun 2014 tentang Rambu Lalu Lintas. Jakarta: Kementerian Perhubungan Republik Indonesia.

Kementerian Perhubungan Republik Indonesia. (2018). Peraturan Menteri Perhubungan Republik Indonesia Nomor PM 67 Tahun 2018 tentang Perubahan Atas Peraturan Menteri Perhubungan Nomor PM 34 Tahun 2014 tentang Marka Jalan. Jakarta: Kementerian Perhubungan Republik Indonesia. 